\title{
Journalism and Mass Communication students at Historically Black Colleges and Universities and Predominantly White Institutions: Saying Goodbye to the Digital Divide
}

\author{
Jerry Crawford II ${ }^{1, *}$ \\ ${ }^{1}$ William Allen White School of Journalism and Mass Communications, University of Kansas, 1435 Jayhawk Blvd., \\ Lawrence, KS 66045-7515, USA \\ *Correspondence: William Allen White School of Journalism and Mass Communications, University of Kansas, \\ 1435 Jayhawk Blvd., Lawrence, KS 66045-7515, USA Tel: 1-804-864-0603 E-mail: jcrawford@ku.edu
}

Received: November 2, 2012

Accepted: November 14, $2012 \quad$ Online Published: April 7, 2013

doi:10.5430/wje.v3n2p1

URL: http://dx.doi.org/10.5430/wje.v3n2p1

\begin{abstract}
The digital divide has been described as the distance or gap in access to information based on race, ethnicity, income, education and geographical location. This study examined how freshmen and first-semester journalism and mass communications students at five Historically Black Colleges and Universities have been able to bridge the divide. It is important to know that HBCUs educate more than African-Americans, however the majority of students at HBCUs come from lower socio-economic levels than students that attend Predominantly White Institutions. The respondents in this study are self-described as daily moderate to heavy Internet users. Their parents and guardians are also frequent Internet users. The study examines the uses and gratifications of the respondents and if their institutions were able to help them find information on school funding. The study's results are completely portable to other disciplines and all colleges and universities regardless of size or scope.
\end{abstract}

Keywords: digital divide; HBCUs; JMC; PWIs; usability

\section{Introduction}

\subsection{There Are Always "Gaps" in Who Has Access to Current Technology and Information}

Throughout the history of the world's societies and cultures there has always been those that have had the then-current "advanced" technology and those that did not have these skills. These advances have been in many different fields, from agriculture to zoological scientific classifications. This study is interested in what many call "the information gap". For most societies, the ability to have information and the ability to read and write determines who will have the ability to rise and maintain their place in the highest socio-economic strata. Learning to read and to write has been a highly regulated privilege in many cultures. Being able to communicate through the printed word is important, because its impact on society can be viewed in full, from the stir made among the literate few by the first inventions in the fifteenth century to the effects of almost universal literacy among the western nations 400 years later (Derry \& Williams, 1961, p. 214).

In the American colonies, the use of print gave rise to revolution against England and the formation of a new government for American independence. Documents, such as Thomas Paine's "Common Sense", were powerful tools in sharing information to everyone in the colonies. In this and other writings Paine advocated a system of checks and balances, separation of church and state, support of universal human rights, the importance of technology to economic development, help for the working poor, and the need to support the union through appropriate taxation (Dennehy, Morgan \& Assenza, 2006). Although Paine and his contemporaries were writing about the freedom of expression and a free press, they were actually advocating for white males, specifically white male landowners.

There were whole sections of the populace living in the colonies that were not given the opportunity to even learn how to read these powerful messages. The American slave was forbidden to learn to read. The overwhelming ethnicity of a slave in America was one of African decent. The process of keeping African slaves and their descendents illiterate 
continued throughout America's history. The common practice of legislating literacy throughout the American South was accepted and had a purpose. Those who chose to break these laws were ostracized or worse. There were several levels of punishment given to those that broke the codes and laws. One such law was enforced in the state of North Carolina.

Any free person who shall teach any slave to read or write upon conviction shall if a white man or woman, be fined not less than 100 dollars, nor more than 200 dollars, or imprisoned; and if a free person of colour, shall be fined, imprisoned or whipped, not exceeding 39 lashes, nor less than 20. And for a similar offense, a slave shall receive 39 lashes on his or her bare back (Accomando, 1998).

It is with these laws as a backdrop that Historically Black Colleges and Universities (HBCUs) were established after the American Civil War. The ability for a country to have a literate and informed citizenry provides for a more democratic governance and society. HBCUs were founded to allow Blacks to teach Blacks. Their missions, among other things, would be to try to close the literacy gap in America.

This study examined how the digital divide pertained to a particular sub-set of people, journalism and mass communication students at Historically Black Colleges and Universities and Predominantly White Institutions. The costs of computer, smart phone, tablet and laptops have been falling in the last 5 years as more and more competitors enter the manufacturing field. No longer can the digital divide be centered on the home desktop computer. People are mobile and are able to access information on a wide variety of devices. The students in this study all owned a smart phone, in which they access the Internet for school and recreation.

The challenge in 2012 is in keeping democracy strong with full access for everyone with high-speed Internet connections. In 1968, The Kerner Report was in response to what many thought was happening to America and said the U.S. was heading toward 'two societies, one black, one white-separate and unequal,' hastened the nation's movement from anti-discrimination to affirmative action policies (Atkinson \& Pelfrey, 2006). The question to answer now is how are African-Americans using the Internet? A 2011 study by the Kaiser Family Foundation found minority children spend an average of 13 hours a day using mobile devices and computers - about $4 \frac{1}{2}$ hours more than white kids (Marcus, 2011). The cost does not seem to be prohibitive to digital device ownership.

\section{Brief history of Historically Black Colleges and Universities}

Although many Historically Black Colleges and Universities were established after the Morrill Act of 1890 provided for state-supported, land grant HBCUs, most were established before 1890. The majority of the HBCUs are located in what is considered the South, or southern geographical area of the United States. Historically Black Colleges and Universities were first established in the United States to meet the educational needs of Blacks who were disenfranchised by the predominantly White population of the country. Most public Black colleges in their early years were true colleges in name only. Cheney State University in Pennsylvania is the oldest, being established in 1837, yet it is outside of what would be considered the region that would characterized these institutions. Most began as primary schools and added upper grades and collegiate divisions as students progressed over the years. For example, as late as 1917, Florida Agriculture and Mechanical College (FAMU) enrolled only 12 students at the collegiate level. In contrast, Justiz et al. (1994) found that all the other Black public colleges combined enrolled 7,500 students in elementary and secondary grades and only 24 in the collegiate curriculum.

The HBCU has not only served as the exclusive avenue of access to higher education for African Americans with its promotion of a participatory ethos and an open door admissions policy, but it has also provided avenues of student leadership potential and social development. Historically, these universities have been under-funded and have had a weaker governance structure than other state supported or private, Predominately White Universities (PWIs). It is also important to note that HBCUs were established for different reasons than traditional schools. Many HBCUs were threatened because they did not have the adequate resources to gain status as an accredited college.

It is with this backdrop of a lack of access to these resources that this study looks at how not only the institutions, but also the students have begun to reach technological levels of equality with other strata of students. Besides the importance of the overall funding needed to make these institutions equal and not separate from other accredited schools, the next critical focus is on the access to information. This basic tenant, as was discussed earlier as the information gap, will be discussed later in this study, the digital divide.

There have been several studies that have looked at African-Americans as a whole in regard to the access of information. This study was more interested in looking at freshmen and first-year students at HBCUs and PWIs with journalism and mass communication units. There has been a paucity of research specifically done on these 
institutions. The importance of journalism students at these institutions in how the graduates enter the media has not been made clear. HBCUs produce $80 \%$ of all African-American media professionals that have graduated from college. These professionals can be a part of the media's decisions, moving forward, in the creation of media images and agendas.

\section{Brief History of HBCUs with Mass Communications and Journalism Programs}

Journalism and mass communication education came late to the more than 104 HBCUs in the United States. Lincoln University in Pennsylvania, founded by Presbyterians, admitted its first students in 1856. During the rest of the nineteenth century, according to Jeter (2002), the private institutions founded by various northern philanthropists and religious denominations and the state institutions established for Blacks generally emphasized a program of study to develop teachers. How did the other HBCUs gain entry into the mass communication industry, while moving from their traditional mission of being teaching and vocational institutions? In the 1970s, funds for mass communication programs at HBCUs came primarily from two sources. The federal government approved HBCU grant proposals to use money available under the Aid for Institutional Development Program (commonly referred to as Title III) to fund journalism and mass communication activities. The W. K. Kellogg Foundation also funded journalism and mass communication program activities at several state HBCUs, several of which are now accredited (Jeter, 2002). The increase in available funding for journalism and mass communication programs coincided with the increase in the number of students that have been enrolling at HBCUs. Howard University in Washington, D.C., with a 2011 reported student enrollment of 10,745 is the largest of the 88 four-year universities.

Crawford (2012) found that as of 2012, there are 49 HBCUs with journalism and mass communications units. These units can be delineated as concentrations, programs, divisions, departments and schools. These 49 units make it possible for African-Americans to help shape the images and messages that are generated by the media. The best way for African-Americans to be a part of the media is to produce students and graduates who are taught the theories and techniques used by the media. HBCUs are producing many students enrolled in mass communication and journalism as minor and major courses of study. HBCUs offering degrees in journalism and mass communication need to be accountable for providing the basic skills and theoretical framework to allow students the ability to compete with students from PWIs for career opportunities.

College enrollment today continues to be diverse. Nearly three in ten of the students at the undergraduate level are racial or ethnic minorities. That ratio has not changed much in recent years White students from the United States made up $72.5 \%$ of the enrolled students in journalism and mass communication programs in the autumn of 2004 . That figure had been $72.1 \%$ a year earlier. African-American students made up $12.1 \%$ of the enrolled students (Becker et al. 2006). That figure has not changed much in the 6 years since that study.

HBCUs are still important in educating, primarily first-generation African-Americans. As found by Lemelle (2002), Howard professor Ralph Bunche, in the 1960s spoke frequently regarding the importance of HBCUs in the African-American community. Young Blacks were looking to the HBCU with high expectations for the education that would prepare them for what they perceived to be a new era of employment opportunities in a rapidly changing world. It must be stated that HBCUs educate not only African Americans in 2012, HBCUs are multicultural and diverse in their student population; however, HBCUs predominantly enroll African Americans. The media message strategies taught to students at HBCUs give the students a strong base in seeking careers in the profession and in theoretical frameworks. The theoretical frameworks taught at not just HBCUs, but also PWIs, such as hegemony and marginalized populations, are important in furthering a more diverse representation of scholars and practitioners because these frameworks detail how and why messages are shown in the media.

How soon are the African-American students that attend HBCUs getting these messages and how are they accessing information? This question brings us to the heart of the study.

\section{What is the Digital Divide?}

The digital divide is the stratification of people according to access to interactive computer-based technologies - on one side, groups and individuals possessing the ability to participate within the network society, and on the other, those who are absent or excluded from it. It is the gap between the information-rich and the information-poor. Clouding the issue of defining the digital divide is that it is not just a gap that exists between developed and developing nations, but also within nations and thus also creating inequality for marginalized communities within developed nations. This aspect of the digital divide reflects a more complex understanding of a centre periphery model of 
development, whereby centers of power as well as peripheries of marginalization exist within all countries (Macleod, 2005).

In America, there were series of riots and civil unrest in the country that was the impetus of President Lyndon Johnson's call for a study to allow Americans to understand how information was disseminated and received via the mass media. According to Mastin (2000), in 1968, the Task Force on Violent Aspects of Protest for the National Commission on the Causes and Prevention of Violence, commonly known as the Kerner Commission Report, discussed the media divide between Whites and African-Americans. The report did bring to light how African Americans and Whites used information with the "news media portrayed the 1967 riots as black-white conflicts rather than placing them in the context of people stressed by deteriorating economic and living conditions.

The digital divide is most often used to refer to differential access to the Internet (Zimmerman \& Meyer, 2005). According to the organization Digital Partnership in Seattle, the term digital divide was first coined during the debate over the Telecommunication Act of 1996 (Feldman, 2000, p. 55). As late as 1999, studies found the digital divide between, at least urban African Americans and Whites, was still a large one. Just 11.8 percent of urban blacks had a computer in their homes, contrasted with 30.3 percent of whites and 13.2 percent of Hispanics, said a 1999 report, 'Falling Through the Net (Dreyfuss, 2001). The report, Falling Through the Net: Defining the Digital Divide, was conducted by the National Telecommunications and Information Administration (NTIA) and examined trends in Americans' access to, and usage of, the Internet, computers, and telephones. It found that, while the overall number of American homes, schools and businesses connected to the Internet is rapidly increasing, a large segment of society, namely people of color, the poor, and residents of rural and inner city communities, are seriously lagging behind in access to this and other types of information technology (Brown, 1999, p. 16). Well-documented inequalities in access to and use of IT such as the computer and Internet reflect existing patterns of social stratification in the United States (Steyaert, 2002). Computers and the Internet have great educational potential because people can use these technologies to access libraries and databases as well as experts who might not be as easily accessible to them through other means, such as the telephone. In addition, asynchronous and synchronous discussions via e-mail or chat systems can support collaborative learning among students in traditional courses who communicate online outside of class time. However, a digital divide continues to separate those students who have access to computers and the Internet through high speed, wide bandwidth connections and those who do not. Research has linked variability in individuals' levels of access to information technologies and variability in individuals' attitudes toward these technologies to socioeconomic status, educational attainment, gender, age, race, family configuration, disability status, and geographic location, in terms of urban/rural locales (Kleinman, 2001).

Diverse groups of individuals from government, education, social work, private foundations, industry, the popular press, as well as parents and youths themselves, have expressed several reasons why the nation should be concerned about the gap between the IT "haves" and "have-nots. These concerns fall into four main themes: educational advantages, future employment and earnings, opportunities for social and civic involvement, and equity and civil rights issues (Eamon, 2004).

\section{Methods and Measures}

The universities in this study were randomly selected from lists from the United States Department of Education and the Journalism and Mass Communication Directory, published annually by the Association for Education in Journalism and Mass Communication (AEJMC). The study's respondents were composed of students from five HBCUs: Albany State University, Howard University, Shaw University, Virginia State University and Xavier of Louisiana. The universities in this study were randomly selected from lists from the United States Department of Education and the Journalism and Mass Communication Directory, published annually by the Association for Education in Journalism and Mass Communication (AEJMC).

All 49 HBCUs with any concentration, unit, department or school of mass communications or journalism were included in the pool of possible schools. Administrators and faculty at all 49 schools were first contacted in March 2011 by emails, when available and by phone calls to the schools. A second contact was attempted in April 2011. A third attempt was made in May 2011 and schools that replied to the inquiries were sent letters and emails regarding the scope of the project. In August 2011, the administrators and faculty were to choose courses at their institutions that would contain primarily freshmen but also could include first-time journalism students. This stipulation was added after being informed many of the institutions did not admit freshmen into the JMC programs. 


\subsection{Student Profiles and IRB Protection}

The faculty of the courses chosen would provide the students in their classes the link to the 25-question Survey Monkey instrument. The survey was provided to 450 students within the 6 universities. There were a total of 431 completed responses for the survey. The respondents included $53.9 \%$ freshmen, $25.3 \%$ sophomores, $16.4 \%$ juniors and $4.2 \%$ transfer students. Also in this number were $1.6 \%$ of transfer students that have earned associate degrees elsewhere. The students were all made aware of Institutional Review Board (IRB) ethical procedures and were given the opportunity to opt into expanding on the survey's questionnaire by giving their direct quotes to be used in the study. Over 20 of the students chose to make statements and to have them used as part of the official study. Student comments were then randomly selected and used to give texture and richness to general survey responses.

\section{Theoretical Framework - Uses and Gratification: The Internet does it all}

Journalism and mass communication students at HBCUs, like most college students, are as susceptible to excessive Internet use than any other age group. The students in this study moved away from home to campus living and even before they arrived, were veteran Internet users and consumers. The question becomes "Why are they using the Internet so much?"

The primary objective of this study was to examine the Internet usage of the JMC HBCU students. Sweester et al (2008) looked at how uses and gratifications research approaches media through a user-level perspective, focusing on the users as an active audience. For online studies, this concept of an active audience is less disputed than with other media because users must actually go online to access information through a more goal-orientated activity. This study fits into their paradigm. Following the uses and gratifications tradition, audiences actively select among news sources based on their ability to gratify their needs for information, entertainment, social interaction, and escapism (e.g., Henke, 1985; Lin, 1993; McDonald, 1990; Parker \& Plank, 2000; Vincent \& Basil, 1997). Sweester et al found that more general studies of the medium report that Internet use provides entertainment and social gratifications for users. Interactive Internet resources typically are driven by social motivations, whereas Internet resource use appears to be driven by informational needs.

The uses and gratifications approach stems from Lasswell's functionalism of the 1940s (Lasswell, 1948). It attempts to explain why people use various forms of media (Katz, Blumler, \& Gurevitch, 1974) and what their motivations are when selecting among media channels and their contents (Ruggiero, 2000). All forms of news media are said to be selected by those with surveillance needs seeking in-depth information and local news, whereas the gratification of surveillance needs has been closely associated with the print media, and television is preferred by those with entertainment and escapism needs. Diddi \& Larose (2006) found that habitual media behaviors may be initiated as actively planned and actively reasoned choices as the uses and gratification model would have it. However, with repetition, media behaviors become less subject to active self-observation as the media consumer conserves mental energy for other, more pressing, daily concerns. Papacharissi \& Rubin (2000) extended uses and gratifications to the Internet and offered new conceptualizations of media attendance that become salient in a media environment that includes interactive options (LaRose \& Eastin, 2004). Therefore, a rapidly changing media environment and new theoretical approaches to the problem of media attendance pose challenges to the existing view of news consumption.

\section{Research Questions - Saying Goodbye: A Generation at a Time}

According to Turner-Lee (2010), while more African Americans and Hispanics are getting online, those getting online tend to be more affluent and better educated. Recent data released by the FCC and the U.S. Department of Commerce affirms this trend. According to the recent FCC Working Paper on broadband adoption and use, fifty-nine percent of African Americans have broadband connections at home, reflecting a considerable increase from the forty-six percent who had adopted broadband at home in 2009. As seen earlier in the study, the parents of these respondents are also Internet and technology users. The students were asked about their portable usage. "Do you own a mobile device that allows you to go online?" (No $=.11 .0 \%$; Yes $=89.0 \%$ ). Howard University freshman, Sade McKoy, said she "Uses here smart phone to access the Internet all the time." Another respondent, Shaw University freshman, William Askew, stated, "I use my Droid Incredible to access my favorite social media sites throughout the day." These students are representative of the responses given for the question and they bring into the question of what these technologically driven African-American JMC students are doing to gain access digital information.

RQ1: How often and active are HBCU JMC students on the Internet and what are they doing there? 
According to a Pew Study, Jones (2001), one-fifth (20\%) of today's college students began using computers between the ages of 5 and 8 . By the time they were 16 to 18 years old all of today's current college students had begun using computers - and the Internet was a common place in the world in which they lived.

This study used as the dependent variable the Internet user and is operationally defined by measuring the amount of time the respondent was actively using the Internet. Two survey questions were used to test this variable: "I primarily use the Internet for" (Social Media $=55.5 \%$; Gaming $=0 \%$; News and Information $=17.2 \%$; Entertainment and Sports $=8.6 \%$; and School Work = 18.8\%), "How would you rate your Internet usage per day?" (Low: 1-2 hours = 11.7\%; Moderate: $3-5$ hours $=58.6 \%$; High: 6 or more $=29.7 \%$ ). These measures represent the time the respondents commit to using the Internet each day and to what purpose.

The respondents of the study gave varied comments on how they used the Internet in their search. A junior from Albany State University considers herself a high Internet and says she uses the Internet primarily for social media. She uses both Facebook and MySpace, but rarely used the Internet in making her school choice decision. A Howard University freshman considers herself a moderate Internet user and says she primarily uses it for news and information. A Xavier of Louisiana junior says he is a high Internet user too and states, "I primarily use the Internet for social media sites like Facebook and Twitter." A a junior transfer student at Howard University, said that just because students use the Internet for social media does not mean they are posting pictures all day long, "Though I can only choose one answer, it is almost tied that I use the Internet for both social media as well as information. Often, as with the DMV earthquake, Osama Bin Laden's death and the execution of Troy Davis, I learned that news or received updates from my social media sites."

The importance of having the ability to access information of all types has not been lost on these African-American JMC students. The digital divide that may exist to other strata of African-Americans, is a foreign concept to the JMC students. An Albany State University senior responded with, "When using the Internet I do mostly use it for social media but I also use it a lot when it comes to my school work."

\subsection{Using the Internet as a Part of College Choice}

The respondents to the survey are all currently enrolled as freshmen or first-year journalism and mass communication students at their current universities. The survey wanted to know if having access to the Internet was important in the ability to research and examine their specific units. The respondents to the survey reported that they received information equally from parents, high school guidance counselors, college fairs \& brochures, and Internet searches. So, how did they make the decision?

RQ2: How often did HBCU JMC students looking to enroll in a specific journalism/mass communication unit visit that program's specific site?

To examine this topic the survey asked two questions, first, "Did you visit your University's website prior to applying?" (No $=8.6 \%$, Yes $=91.4 \%)$. Again, drilling deeper for the "yes" responses (Yes: $1-5$ times $=25.8 \%$, Yes: More than 5 times $=21.9 \%$ and Yes: I was on there every week or so $=24.2 \%$ ).

The second question asked, "Did you visit the department/major's website prior to applying?" (No $=36.8 \%$, Yes: 1-5 times $=57.6 \%$, Yes: I was on there every week $=5.6 \%$ ). These measures represent the amount of time the respondents committed to considering the school and the unit's web pages prior to applying to the school.

By simply examining these two responses it is clear that $91.4 \%$ of the respondents visited the University's website, yet only $63.2 \%$ of the respondents took the opportunity to view and explore their individual unit's website for further information. A Xavier of Louisiana sophomore, a moderate Internet user, said she did not know her department had an accessible website. In fact she stated, "It did not exist." Xavier sophomore, a first time journalism student, says she visited the University's website 1-5 times but never visited the department's website prior to applying and entering the school. An Albany State University transfer student said, I was on the University's main website more than 5 times, but I never thought to see if my department had a separate webpage."

Why are there disconnects from site to site? Why are the students not finding easier links to the departments? Is it a matter of website usability?

\subsubsection{Usability: Do HBCU JMC Students Perceive Their Units' Web Pages to be User Friendly?}

Usability. In his book, "Designing Web Usability", Jakob Nielsen states, "The Web is the ultimate customer empowering environment. He or she that clicks the mouse gets to decide everything" (Nielsen, 2000). If a site is not immediately interesting or the audience is not impressed that first impression is lasting. "It is so easy to go elsewhere; all the competitors in the world are but a mouse click away" (Nielsen, 2000). It seems as though JMC units need to 
do a better job of promoting and strategically placing their web pages in concert with the design of the University's templates. This may not be possible and they may not have the flexibility to do this but it is a topic they could use and can point to the results of this study. Poock \& Lefond (2001) studied college bound high school students and found that virtually all of them relied upon the Web when applying to colleges or universities. According to Feeney (2009) more and more students are looking at colleges based on the Internet, and more and more admissions offices are looking at the Internet as a tool. Kung Fong (2010), found that usability guidelines such as these provide designers of online experiences the rules and/or principles they need to follow to provide conditions for better navigation which in turn contributes to a better experience; an experience that is uninterrupted; one that allows for seamless navigation and acquisition of information; one that makes sure users don't have to think to access information they need.

\subsubsection{HBCU JMC Students: Putting Information Accessibility to the Test}

The respondents were asked if they were able to use the Internet to find information regarding funding on their school's website that would help them in make a decision to apply to the institution.

RQ3: Was financial aid and scholarships important to you in making your college choice?

The respondents to this survey were asked, "Was financial aid important in your decision to attend your institution?" The answer to this question possibly gives an insight into the students' socio-economic backgrounds (No $=27 \%$, Yes =73). A freshman at Howard University, said that financial aid was very important, but she was not aware of any departmental scholarships she may have been qualified to apply for which would helped her in making plans for paying for college. A freshman at Albany State University commenting about financial need, seconds this view. He was interested in knowing about financial aid but was not aware of any help within his department. Is this a usability problem or is it an oversight for so many of the JMC units?

Federal and state budgets are being downsized and Education has taken its share of hits in the recent months. African-American JMC students, particularly those attending HBCUs, are dependent on financial aid and available scholarships. HBCUs historically provide education to students that are not able to pay the full cost of college. Students that traditionally attend HBCUs come from low-income families and HBCUs have missions that require the institutions to provide the ability for the students to attend. Brown \& Freeman (2004) state that in short, both student opportunity and HBCU enrollments depend upon financial aid packages. This is not to imply that White students' families do not face financial hardship. In fact, President Barack Obama, in his 2012 State of the Union Address, stressed the importance of the help that all Americans are now facing.

When kids do graduate, the most daunting challenge can be the cost of college. At a time when Americans owe more in tuition debt than credit card debt, this Congress needs to stop the interest rates on student loans from doubling in July. Extend the tuition tax credit we started that saves millions of middle-class families thousands of dollars, and give more young people the chance to earn their way through college by doubling the number of work-study jobs in the next five years. Of course, it's not enough for us to increase student aid. We can't just keep subsidizing skyrocketing tuition; we'll run out of money. States also need to do their part, by making higher education a higher priority in their budgets. And colleges and universities have to do their part by working to keep costs down. (President Barack Obama State of the Union Address 2012)

RQ4: Are journalism/mass communication units providing effective information on their sites about financial aid and scholarships?

This study found that the JMC units are not doing a good job of providing prospective students with enough information on these topics. The survey asked, "Please rate the experience you had in accessing and understanding financial aid and department scholarships." In regards to financial aid, a composite result was (Helpful $=24.0 \%$; Somewhat helpful $=42.4 \%$; Difficult $=18.4 \%$; Somewhat difficult $=7.2 \% ; \mathrm{N} / \mathrm{A}=8.0 \%$ ).

In response to scholarships, a composite result was $($ Helpful $=12.1 \%$; Somewhat helpful $=30.6 \%$; Difficult $=20.2 \%$; Somewhat difficult $=6.5 \%$; and $\mathrm{N} / \mathrm{A}=30.6 \%$ ). These numbers are not favorable for JMC units interested in marketing their funding assistance programs for prospective students. When looking at the rankings, the respondents consider their units only $66.4 \%$ favorable in providing financial aid information. The same group rates the units $42.8 \%$ favorably regarding scholarship funding information on their websites. A good example of this is from an Albany State University freshman who thought the school was helpful in providing financial aid information, but did not know about scholarships and put N/A for that category. 


\section{Findings and Discussion}

This study set out to explore if the digital divide was still a factor in how African-American JMC students at HBCUs were able to access information and their Internet usage. The complexity of the digital divide is often misunderstood and oversimplified. The digital divide is not simply that Black households experience the lowest rate of computer ownership and Internet access. The implications of the digital divide for the education and the lives of students are more complicated than not having a computer, Internet access, and an e-mail address. The digital divide represents a racial and economic gulf in access to computer hardware, software, and training. It also results in providing Black students fewer opportunities to play a role in the development of online learning content (Winston, Philip \& Lloyd, 2007).

This study found the gap in information access is closing. African American college freshmen/first semester mass communication and journalism students may not be suffering from this divide as much as in years past. It seems as though they have access to digital technologies and the Internet. In fact, it seems the digital divide may be more of perception than reality, when it comes to access to technology. The cost of the devices and the cost of high-speed versus dialup phone modem Internet could be the new divide parameters.

\subsection{Home Members' Access to Computers and the Internet}

The first sets of independent variables derive from the respondents' type of Internet usage and access. These include background information such as: home access, parents' usage and school/mobile device access of the respondents. Home access was measured by the question, "Was there a computer with Internet access in your home while you were in high school?" (No $=3.9 \%$; No: I used computer at school $=4.7 \%$; Yes $=91.4 \%$ ). The "yes" answers were further defined as by some of the respondents: (Yes: 1 tower for family use $=18.0 \%$; Yes: 1 laptop for my use $=6.3 \%$; and Yes: multiple computers $=32.8 \%$ ). The study also wanted to explore the question as to the respondents' parents' computer skills. The question asked was, "Are your parents or guardians Internet users?" (No $=10.4 \%$; Yes $=89.6 \%$ ). This response shows how the last two generations of African-Americans in this study have become heavy computer and Internet users. Interestingly and equally important, are the comments made by some of the respondents to this question. A freshman at Howard University stated, "My mother is a writer and my father is a minister, they need computers to work." An Albany State University freshman, wrote, "One parent. The other does not use the Internet." This comment is interesting because she also responded in the survey as having multiple computers within her household.

The study found students that attend HBCUs still report the availability of financial aid and other funding as a major reason they make their college choice. The study also found JMC units as a whole may not be providing this information to students that are using the Internet. Several of the respondents chose, through full disclosure of IRB protection, to add their additional comments as part of their survey. This study could be helpful for every discipline and every size college or university that is interested in using the Internet as a recruiting and retention tool in the future. Strategies such as being more active in social media on their websites and providing easier linkage from home pages to individual units will make the sites more attractive to prospective and current students. One Howard University sophomore considers herself a moderate Internet user, and is online 3-5 hours a day. She visits her school's and her unit's web pages every week or so. She stated, "I could not imagine living in a world without the Internet."

\section{Conclusions and Recommendations}

It is apparent this study is limited in both the number and specificity of the respondents. One limitation was the use of the survey to measure students that self-reported and not being able to have more face-to-face interviews and focus groups to allow for more expansive responses. The other was having a small, but representative sample. Future research should include more schools and a possible longitudinal study over a two or three year college choice cycle with high school students prior to their decisions. The research should also include more identifiers such as the socio-economic and geographical information of the respondents. The study does, however show that the digital divide in a particular stratum has diminished. It is by no means closed for everyone. Today, Internet use continues to increase. Turner-Lee (2010) found that more than seventy percent of Americans are online, and use of social networking sites has tripled. College-educated, affluent minorities that were previously the slowest to use the web are now more prevalent users.

The strength of the study is that it can be used universally for other disciplines in two-year colleges, junior colleges and major four-year Research I universities, by simply asking the same questions to their incoming freshmen class. Other departments on campuses, such as student success, recruiting and retention, can also use the study. 
The digital divide will continue to be important to America and the world community because it is an equalizer to all people that are classified as outside the hegemonic strata within every society. The more people are able to access information and be connected to that information, the more they will be able to succeed.

\section{References}

Accomando. C. (1998). "The Laws Were Laid Down to Me Anew": Harriet Jacobs and the Reframing of Legal Fictions. African American Review, 32(2), 229-245. http://dx.doi.org/10.2307/3042121

Atkinson, R. C., \& Pelfrey, P. A. (2006). Opportunity in a Democratic Society: Race and Economic Status in Higher Education1. Proceedings of the American Philosophical Society, 150(2), 318-332.

Brown, J. (1999). The Digital Divide. Civil Rights Journal, 4(1), 16.

Crawford, J. (2012). A link to the future: A pilot study look at how historically black colleges and universities with journalism and mass communications units use the Internet in recruiting. Contemporary Issues in Education Research, 5(2), 47-60.

Dennehy, R. F., Morgan, S., \& Assenza, P. (2006). Thomas Paine: Creating the New Story for a New Nation. Tamara Journal of Critical Organisation Inquiry, 5(3/4), 183-192.

Derry, T. K., \& Williams, T. I. (1961). A Short History of Technology from the Earliest Times to A.D. 1900. New York: Oxford University Press.

Diddi, A., \& Larose, R. (2006). Getting Hooked on News: Uses and Gratifications and the Formation of News Habits among College Students in an Internet Environment. Journal of Broadcasting \& Electronic Media, 50(2), 193-210. http://dx.doi.org/10.1207/s15506878jobem5002_2

Dreyfuss, J. (2001, January 1). Black Americans and the Internet: the Technological Imperative. National Urban League. The State of Black America 131.

Eamon, M. K. (2004). Digital Divide in Computer Access and Use between Poor and Non-Poor Youth. Journal of Sociology \& Social Welfare, 31(2), 91-112.

Feeney, N. (2009). Getting Personal: How Colleges and High School Students Connect Online. Journal of College Admission, (203), 4-7.

Feldman, G. (2000). The Dark Side of the Internet: Divided about the Digital Divide. The Public Manager, 29(4), 55-58.

Henke, L. L. (1985). Perceptions and use of news media by college students. Journal of Broadcasting \& Electronic Media, 29, 431-436. http://dx.doi.org/10.1080/08838158509386598

Jeter, P. (2002). Journalism and mass communication education at HBCUS: History and current issues. Education, 123(1), 200-223.

Justiz, M. J., Wilson, R., \& Björk, L. G. (Eds.). (1994). Minorities in higher education. Phoenix: Oryx Press.

Katz, E., Blumler, J., \& Gurevitch, M. (1974). Utilization of mass communication by individual. The uses of mass communications: Current perspectives on gratifications research. Beverly Hills. Sage. 20-30.

Kleinman, S. S. (2001). Understanding the Digital Divide: Implications for College Teaching. Transformations, 12(2), 51.

Kung Fong, M. W. (2010). Audience/online Information Interactions: New Research in Learning Preferences. Visible Language, 44(3), 279-303.

LaRose, R., \& Eastin, M. S. (2004). A social cognitive theory of Internet uses and gratifications: Toward a new model of media attendance. Journal of Broadcasting \& Electronic Media, 48, 358-377. http://dx.doi.org/10.1207/s15506878jobem4803_2

Lasswell, H. D. (1948). The structure and function of communication in society. In L. Bryson (Ed.), The communication of ideas (pp. 37-51). New York: Institute for Religious and Social Studies.

Lemelle, T. J. (2002). The HBCU: Yesterday, today and tomorrow. Education, 123(1), 190-218.

Lin, C. A. (1993). Modeling the gratification-seeking process of television viewing. Human Communication Research, 20, 224-244. http://dx.doi.org/10.1111/j.1468-2958.1993.tb00322.x 
Macleod, H. (2005). What Role Can Educational Multimedia Play in Narrowing the Digital Divide? International Journal of Education and Development using Information and Communication Technology, 1(4), 42-53.

Marcus, M. (2011, June). Minority kids spend most of their waking hours plugged in. Retrieved from http://yourlife.usatoday.com/parenting-family/story/2011/06/Minority-kids-spend-most-of-their-waking-hours-p lugged-in-/48172486/1?loc=interstitialskip

Mastin, T. (2000). Media Use and Civic Participation in the African-american Population: Exploring Participation among Professionals and Nonprofessionals. Journalism and Mass Communication Quarterly, 77(1), 115-127. http://dx.doi.org/10.1177/107769900007700109

McDonald, D. G. (1990). Media orientation and television news viewing. Journalism Quarterly, 67, 11-20. http://dx.doi.org/10.1177/107769909006700103

Nielsen, J. (2000). Designing web usability. Indianapolis, IN: New Riders Publishing.

Papacharissi, Z., \& Rubin, A. M. (2000). Predictors of Internet usage. Journal of Broadcasting \& Electronic Media, 44, 175-196. http://dx.doi.org/10.1207/s15506878jobem4402_2

Parker, B. J., \& Plank, R. E. (2000). A uses and gratifications perspective on the Internet as a new information source. American Business Review, 18, 43-49.

Poock, M. C., \& Lefond, D. (2001). How College-bound Prospects Perceive University Web Sites: Findings, Implications, and Turning Browsers into Applicants. College and University, 77(1), 15-21.

Ruggiero, T. (2000). Uses and gratifications theory in 21st century. Mass Communication \& Society, 3, 3-37. http://dx.doi.org/10.1207/S15327825MCS0301_02

Steyaert, J. (2002). Inequality and the digital divide: Myths and realities. In S. E Hick \& J. McNutt (Eds.), Advocacy, Activism and the Internet (pp. 199-211). Chicago: Lyceum Press.

Sweetser, K. D., Porter, L. V., Chung, D. S., \& Kim, E. (2008). Credibility and the Use of Blogs among Professionals in the Communication Industry. Journalism and Mass Communication Quarterly, 85(1), 169-185. http://dx.doi.org/10.1177/107769900808500111

Turner-Lee, N. (2010). The Challenge of Increasing Civic Engagement in the Digital Age. Federal Communications Law Journal, 63(1), 19-32.

Van Staveren, T., \& Dale, D. (2004). Childhood Obesity Problems and Solutions: Food Choices and Physical Activity, at School and at Home, Underlie the Childhood-Obesity Problem. What Role Can Schools Play in Finding a Solution?. JOPERD--The Journal of Physical Education, Recreation \& Dance, 75(7), 44-49. http://dx.doi.org/10.1080/07303084.2004.10607274

Vincent, R. C., \& Basil, M. D. (1997). College students' news gratifications, media use, and current events knowledge. Journal of Broadcasting \& Electronic Media, 41, 380-392. http://dx.doi.org/10.1080/08838159709364414

Winston, C. E., Philip, C. L., \& Lloyd, D. L. (2007). The Identity and Success Life Story Method: a New Paradigm for Digital Inclusion. The Journal of Negro Education, 76(1), 31-42.

Zimmerman, J. N., \& Meyer, A. (2005). Building Knowledge, Building Community: Integrating Internet Access to Secondary Data as Part of the Community Development Process. Journal of the Community Development Society, 36(1), 93-102. http://dx.doi.org/10.1080/15575330509489874 